\title{
Inhalt, Vol. 8, No. 5, 1985
}

\section{Contents}

Impressum

Vorwort

252

Diagnostik

Kreienberg, R. und Melchert, F., Mainz

Neuentwicklungen auf dem Gebiet der Marker zur Diagnostik

und Überwachung des Ovarialkarzinoms 253

Schröck, R., München; Hafter, R.; Graeff, H. und

Schmid, L., Oberstaufen

Die simultane Bestimmung von Ca 125 und D-Dimer im Plasma

und Aszites beim Ovarialkarzinom 260

Sonderbände 262

Schillinger, H. , Freiburg i. Br.

Sonographie zur Früherkennung und zur Entscheidung der

Dignität 264

Rohde, U.; Becker, H.; Weigert, F. und Lindner, P. , Passau Computertomogramm in der

Diagnostik des Ovarialkarzinoms . 272

Hinweise für Autoren 275

Neuigkeiten für die klinische Praxis 276

Dietel, M. undArps, H., Hamburg

Morphologie und Wachstumsverhalten von Ovarialtumoren . . . 278

Rundtischgespräch «Staging»

Leitung: H. Schmidt-Matthiesen (Frankfurt) 286

Primärtherapie beim begrenzten Ovarialkarzinom

Meerpohl, H. G., Freiburg i. Br.

Prognosefaktoren des Ovarialkarzinoms 296

Bender, H. G., Düsseldorf

Die radikale Tumoroperation beim begrenzten Ovarialkarzinom 306

Frischbier, H.-J. und Bahnsen, J., Hamburg

Die Strahlentherapie beim primär radikal operierten Ovarial

karzinom $\quad 310$

Illiger, H. J.; del Valle, F. und Mühlenstedt, D., Oldenburg

Adjuvante Chemotherapie beim primär radikal operierten

Ovarialkarzinom $\quad 316$

Rundtischgespräch «Die Therapie begrenzter, maligner Ovarial

tumoren anhand exemplarischer Fälle»

Leitung: A. Pfleiderer (Freiburg) 324

Onkologie-Mitteilungen 332

Alle publizierten Arbeiten wurden anläßlich des Symposiums 
«Das Ovariaîkkarzinom» der AIO, ARO und AGO

in Hamburg, 2.-3.11.1984, vorgetragen.

Teil II wird in der ONKOLOGIE 6/Dezember 1985 publiziert.

Imprint250

Preface252

Diagnostic

Kreienberg, R. and Melchert, F, Mainz

New Developments in Diagnosis and Surveillance of Ovarian

Carcinoma 253

Schröck, R., München; Hafter, R.; Graeff, H. and

Schmid, L., Oberstaufen

Simultaneous Determination of CA 12-5 and D-Dimer in Plasma

and Ascites of Ovarian Carcinoma 260

Special Editions 262

Schillinger, H., Freiburg i. Br.

Ultrasound in Early Diagnosis and Determination of Dignity . . 264

Rohde, U.; Becker, H.; Weigert, F. and Lindner, P., Passau Computer Tomography in Diagnosis of Ovarian Carcinoma . . . 272

Instructions for Authors 275

News for Clinical Practice 276

Dietel, M. andArps, H., Hamburg

Morphology and Proliferation Kinetics of Ovarian Carcinoma . . 278

Round-Table Discussion "Staging”

Chairman: H. Schmidt-Matthiesen (Frankfurt) 286

Primary Therapy in Localized Ovarian Carcinoma

Meerpohl, H. G., Freiburg i. Br.

Prognostic Factors in Ovarian Carcinoma 296

Bender, H. G., Düsseldorf

Radical Tumor Resection in Localized Ovarian Carcinoma . . . 306

Frischbier, H.-J. and Bahnsen, J., Hamburg

Radiation Therapy in Radical Resected Ovarian Carcinoma . . . 310

Illiger, H. J.; del Valle, F. and Mühlenstedt, D., Oldenburg

Adjuvant Chemotherapy in Radical Resected Ovarian Carci

noma 316

Round-Table Discussion “Therapy of Localized Malignant

Ovarian Carcinoma in Individual Cases”

Chairman:^. Pfleiderer (Freiburg) 324

Oncology Communications 332

All published lectures have been presented in a Symposium on "Ovarian Carcinoma" of the AIO, ARO, and AGO, Hamburg, Nov 2-3,1984. Part II will be published in ONKOLOGIE

6/December 1985.

Bibliographischer Hinweis: Inhaltsverzeichnisse dieser Zeitschrift erscheinen regelmäßig in current contents ${ }^{\circledR}$ sowie in anderen bibliographischen Diensten. 